\title{
リニアメントの断裂系としての特性とその評価
}

\author{
井上大榮 $* 1$, 水落幸広 ${ }^{* 2}$, 桜田裕之 ${ }^{* 3}$
}

\section{Geological Characteristics of "Lineament" and its Evaluation on Fractured System}

\author{
Daiei INOUE*1, Yukihiro MIZUOCHI ${ }^{* 2}$ and Hiroyuki SAKURADA*3
}

Key words : リニアメント lineament，評価 evaluation，断層 fault，破确幅 fractured width

\begin{abstract}
Recently, the relationship between lineaments and fracture systems has been discussed by some statistic approach. In this study, the criterias for the interpretation of lineaments using Landsat TM, Spot and aerial photograph imagery are proposed for the detection of fractured zones through lineaments. In order to clarify this criteria which are divided into 6 ranks, ranging from A to F, the six sites including USA are studied.

Field evidence shows that many lineaments coincide with faults or joints and it's probability of the coincidence between lineaments and faults or joints is restricted by the length of lineaments. The lineaments length of the 100 percent probability to coincide lineaments with faults or joints agree with the linear part which is called fractal distribution in the relationship between lineaments length and frequency.

In addition, the relationship between lineaments criteria and the width of the fractured zones have a good harmony. High ranking lineaments are very useful in the interpretation of geological structures.
\end{abstract}

\section{1. はじめに}

地質に関するリモートセンシングには，スペクトル解 析による岩相判別とリニアメント解析による地質構造解 析の 2 つの流れがあり, 後者は判読で得られたリニア メントからその地域の断裂系を把握するのに用いられて いる。特に石油・非鉄金属や地熱などの資源探査におい ては, 広域地質構造を把握するために衛星画像や空中写

*1 財)電力中央研究所 我孫子研究所 Central Research Institute of Electric Power Industry, Abiko Research Laboratory

*2 住友金属鉱山(侏資源事業部 Sumitomo Metal Mining Co., Ltd., Mineral Resources Division

*3 住鉱コンサルタント(侏札幌支店 Sumiko Consultants Co., Ltd., Sapporo Branch
真を利用したリニアメントによる地質解析が行われて いる1)。また，土木地質分野においてもリニアメント判 読が活断層 2 (3) や断裂系調查 ${ }^{4}$ に用いられている。

しかしながら，具体的な構造物の設計などに対して， 活断層を対象とするもの 2),3)を除いては, リニアメント そのものの成因を個々に議論した例は少なく，統計的相 似性から断裂系との関係を論じているのが現状である5)。 従来, リニアメントは地質構造解釈の手段として用いら れているが，それが現地に抢いては，どのような地質現 象と対応するかについての研究例は極めて少ない。この ため,リニアメントと地質的特徵との関係を明らかに し，リニアメントの評価方法を確立することを目的とし て, リニアメントの判読方法について評価基準を作成 し, 多くの地点に適用し, その結果を現地調査で検証し た。調査は以下の項目にまとめられる。 
(1)リニアメント判読の基準作成（ランク区分）

(2) 6 地域におけるリニアメントと地質構造の対応関 係の調査

(3)リニアメントのランクと断層破砕幅の関係

リニアメント判読にはランドサットTM 画像を用い, さらに，ランドサットTM 画像では検出限界に近い長 さ 5〜10 km より短いリニアメントについては，スポッ ト画像や空中写真を用いた。

\section{2. リニアメントの定義とその特性}

\section{1 リニアメントの断裂系としての性質}

リニアメントは，地形の “不連続”点が直線上に配列 する場合に認識される。この用語は $\mathrm{HOBBS}^{6}$ によよって

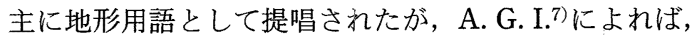
線状に配列する地形形状が地質構造に支配されたとする 考え方が強くなり，ほぼ定着するようになった。しかし ながら，我々が認識できる不連続地形の直線的な配列は 浸食作用や構造運動等によって形成された形態であっ て，断裂系にコントロールされた地形のみを判読してい るわけではない。断裂系のほかに層理面や片理面などの 不連続面によって地形がコントロールされている場合も あり，その区別の指標を得る必要がある。

山口・長谷 ${ }^{5)}$ は, リニアメントと断裂系の関係をリニ アメントの長さ $(L)$ と頻度 $(N)$ が両対数で直線関係 になる区間が断裂系の規模別頻度分布の特性と類似して いることから，リニアメントから対象地域の断裂系の長 さ別頻度分布が推定できるとした。また小島・大野・亀 谷8)や佐藤・市川 ${ }^{9)}$ は，岩盤中の割れ目に関して，割れ 目の幾何学的な分布や性状についてフラクタル的性質が 成り立つことを示している。大野・小島10) はランドサ ット画像や空中写真でのリニアメントの長さ $L$ と頻度 $N$ が岩盤中の割れ目と同様のフラクタル次元の直線に なることを示している。このように，リニアメントと断 裂はその統計的相似性においては類似した性質を有する ことが報告されている。

\section{2 リニアメントの断裂としての検証例}

判読されたリニアメントと地質的特徵との関連性につ いて確認された例をいくつか紹介する。

(1)星野・松野11), 星野・長谷 ${ }^{12)}$ は, 従来, 東西性の 1 本の断層と考えられていた神縄断層が南北性のリニア メントに分断されているとし，現地調査でリニアメント に対応する断層の存在と切断関係を確認した。(2)村岡 ・長谷 ${ }^{13)}$ は, 定向性のあるリニアメントと現地での小 断層との対応を調査した。その結果，九州北部更新世玖 珠層（湖成）ではランドサット画像，レーダ画像，空中
写真でのリニアメントの方向と地表での小断層とが極め て良い対応が見られたのに対して，八幡平鮮新世〜更新 世玉川溶結凝灰岩では良い対応関係が見られなかったと している。さらに，(3)山口ほか ${ }^{14)}$ は秋田県小安温泉付 近での断裂密度の計測でリニアメントが断裂密度の極大 值を示す部分に通過することを示したが，この付近では 破砕帯を伴うような断層は認められなかったとして，リ ニアメントは節理の密集帯を反映したものと結論づけ た。

\section{3. 断裂系評価のためのリニアメントの判読基準}

\section{1 リニアメント判読の要素}

一般に，リニアメントとして判読される地形形状の不 連続点の地形要素としては, 直線谷・屈曲谷・屈曲尾根

・鞍部・孤立丘・段差地形・直線崖などが挙げられる。

リニアメントの判読過程には, (1)使用する画像の種 類，(2)縮尺および分解能，(3)個人差などに影響を受ける ことがあり, 客観的なデータとしての取扱いが困難であ る。山口・長谷 ${ }^{5)}$ はランドサット画像, 空中写真, レー ダ画像によるリニアメント抽出結果の比較検討から, 画 像の種類（1)）が解析結果にどのように反映されるかを 検討し，最適な画像縮尺 $(R)$ と分解能 $(S)$ の関係 (2) を示した。本研究の判読基準作成に際して, $R$ と $S$ の 関係を目的に応じて選定するようにし，また，上記の(3) の問題点については抽出環境を一定にし, 複数の人間に よる判読によって個人差を減じた。

ランドサット画像の判読は, 分解能の問題から上記の 地形要素のすべてを識別できるわけではない。また，太 陽光による陰影によって立体感が得られているが，おく までも 2 次元平面の情報であり，季節によって太陽高 度が異なるために山岳地域などの急峻な地形ではレーダ 画像と同様な疑似的なリニアメント15),16) も観察される ことがある。そこで，直線谷とそれ以外の “不連続”地 形を判読上の地形要素とした。判読に当っては, 直線谷 や不連続地形を境にしての肌理や高度差の有無, ならび にリニアメントの系統性（リニアメントの方向性や形態 の類似性）を重視した。

これに対して，スポット画像および空中写真の判読で は高度が誇張されることによる効果があるものの，3 次 元情報であることから，上記の地形要素は判読可能であ り，直線谷や不連続地形および系統性を要素としてリこ アメント判読基準を作成した。

\section{2 リニアメントの評価方法}

リニアメントの評価は, 従来, 判読者の主観によって 明瞭，不明瞭といった区分がなされている場合が多い。 
表-1 リニアメントの評価（ランク区分）基準表

\begin{tabular}{|c|c|c|c|c|}
\hline ランク & 地質現象 & リニアメントの明瞭度 & リニアメントの連続性 & 利用䛨”仍 \\
\hline A & $\begin{array}{r}\text { 地質構造線 } \\
\text { なと }\end{array}$ & 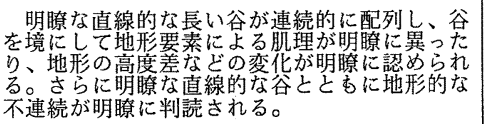 & 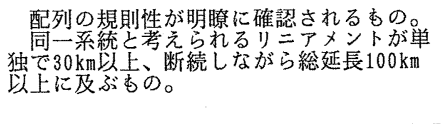 & \\
\hline B & 大規模断層 & 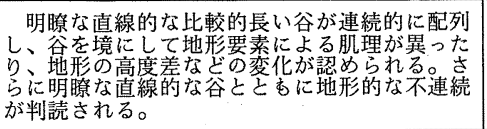 & 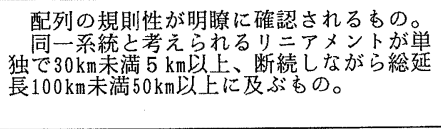 & $\begin{array}{l}\text { ラ } \\
⿱ 亠 䒑 \\
\text { F } \\
+\end{array}$ \\
\hline $\mathrm{C}$ & 中規模断層 & 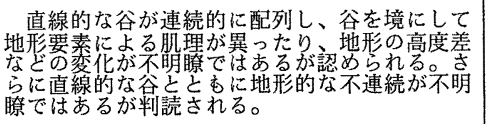 & 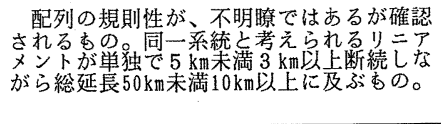 & $\begin{array}{l}\mathrm{T} \\
\mathrm{M} \\
\text { 曹 } \\
\text { 像 }\end{array}$ \\
\hline $\mathrm{D}$ & $\begin{array}{l}\text { 小規模断層 } \\
\text { 卓越節理 } \\
\text { 集合体 }\end{array}$ & 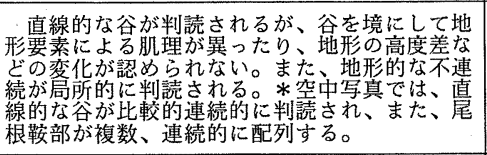 & 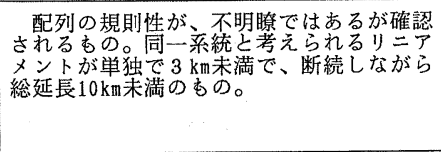 & $\begin{array}{ll}\text { 小 } & \text { 空 } \\
\text { 襾 } & \text { 中 } \\
\text { 象 } & \end{array}$ \\
\hline $\mathrm{E}$ & $\begin{array}{l}\text { 小規模断層 } \\
\text { 卓越節理 }\end{array}$ & 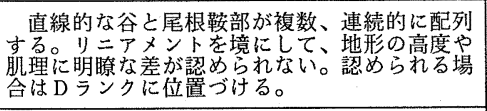 & $\begin{array}{c}\text { リニアメントが単独で } 2 \mathrm{~km} \text { 程度。 } \\
\text { また断続しながら総延長 } 5 \mathrm{~km} 末 \text { 満のあ。 }\end{array}$ & \\
\hline $\mathrm{F}$ & 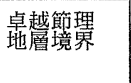 & 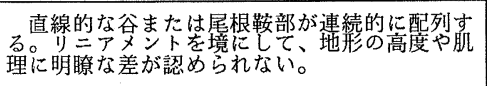 & 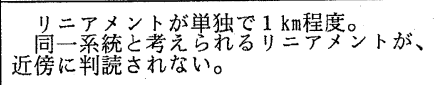 & \\
\hline
\end{tabular}

しかしながら，リニアメントと断裂系の関係を明らかに するには，リニアメントの標準化が必要である。そこ で,リニアメントの有する「明瞭度」と「連続性」から ランクづけを行った。明瞭度は地形的な不連続性に重点 を置き,リニアメントを境にしての肌理や高度の差の有 無から判断した。また, 連続性はリニアメントの単独で の長さと構造地質学的な側面からその系統性を考慮した 長さから判断した。以下の議論ではリニアメントの長さ （もしくはリニアメント長）は単独での長さを示し，ラ ンク区分においては単独もしくは複数のリニアメントの 長さの総和を用いている。明瞭度と連続性を主な要素と したリニアメントのランクづけの基準を表 -1 に示す。 この評価基準は主としてランドサット TM 画像では $\mathrm{A}$ ランクからCランクを，スポット画像ならびに空中写 真では B ランクから F ランクを判読できるようになっ ている。

\section{4. リニアメントとその地質的特徵との関係}

リニアメントの成因は，これまでは経験から断裂系に 求めている。しかしながら，どのようなリニアメントが 断裂系に一致するかについての具体的な検討例は少な い。このため本研究では, 前述したリニアメント判読基 準から得られたランクを基に，リニアメントの成因につ いて現地検証を行った。

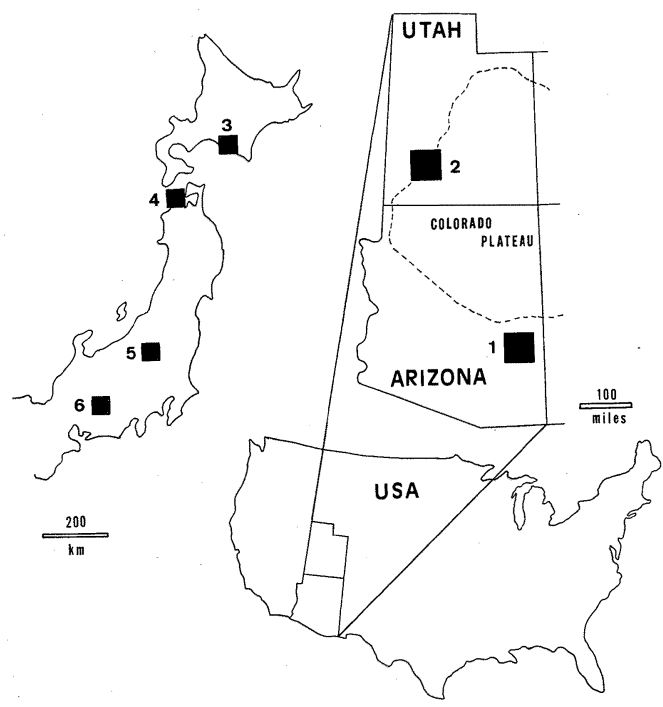

図-1 調査地域位置図

$1:$ アリゾナ州モレンシー地域 $2:$ ユタ州ビーバー地域 $3:$ 北海道中南部地域 5 : 新潟県東南部地域

$4:$ 青森県北西部地域 6 : 岐阜県東南部地域

\section{1 検証方法}

現地検証は，まずはじめに露頭条件の比較的良い海外 の半乾燥地域 2 地域で実施し, 次に, わが国の 4 地域 でその適用性を検討した（図－1）。日本列島は植生が 多く, 浸食作用が卓越し, 地質学的に変動帯であるとい 
う「場」を考慮する必要があり,わが国で適用が可能か どうかの現地検証調查が不可欠である。検証に当って は，次のような基準を設けた。

(1)リニアメントが断層と対応する場合：リニアメン 卜沿いに断層の露頭を 1 力所以上確認することを条件 とする。リニアメント沿いとはその両側約 $50 \mathrm{~m}$ 以内と し, また, 断層の走向はリニアメントの走向と $15^{\circ}$ 以内 で一致するものとした。また，現地調査以外に既存の地 質図で現地を確認していると記載されている断層に一致 する場合も断層とした。

(2)リニアメントが節理と対応する場合：リニアメン 卜沿いに節理の集合帯の露頭を 1 箇所以上確認するこ とを条件とする。本論では節理は単独のものを示すので はなく, 節理の集合体（節理群）として扱う。(1) と同様 に, リニアメント沿いとはその両側約 $50 \mathrm{~m}$ 以内とし, また, 主要な節理の走向はリニアメントの走向と $15^{\circ}$ 以 内で一致するものとした。

(3)リニアメントが岩相境界上対応する場合：リニア メントを境にして両側の岩相が異なり, 地質構造に差が 認められず，岩相境界がリニアメントと同方向を示し， な㧍かつ(1)の断層や(2)の節理が認められないことを条件 とする。

(4)リニアメントと地質との関係が不明とする場合 : 露頭がない場合や露頭があっても上述の(1)から(3)に示す リニアメントと対応する地質現象が認められない状態を いう。

\section{2 リニアメント判読結果と分布の特徴}

検証地域としての海外の 2 地域のうち，モレンシー 地域ではランドサット TM 画像（分解能 $30 \mathrm{~m}$, 縮尺約 10 万分の 1 ), ビーバー地域では空中写真（縮尺約 2 万 分の1）を用いてそれぞれ目視で判読を行い，各リニア メントについて前述した評価方法で評価を行った。

さらに, 日本国内の以下の 4 地域を対象に同様の評 価基準を用いて判読し，現地検証を行った。判読はスポ ット画像（パンクロモード, 分解能 $10 \mathrm{~m}$ ) のオリジナ ルフィルム（縮尺40万分の 1）を拡大し， 5 万分の 1 の 縮尺の画像を用いて目視判読で行った。

なお，わが国で対象とする地域については，導水路卜 ンネルもしくは道路・鉄道トンネルの精密な地質データ を有する地域を選定したため，地下の断裂データを主体 に, 地表踏查により地表の断裂データを追加してリニア メントと地質構造との関係を検討した。

(1)米国アリゾナ州モレンシー地域

(2)米国ユタ州ビーバー地域

(3)北海道中南部地域

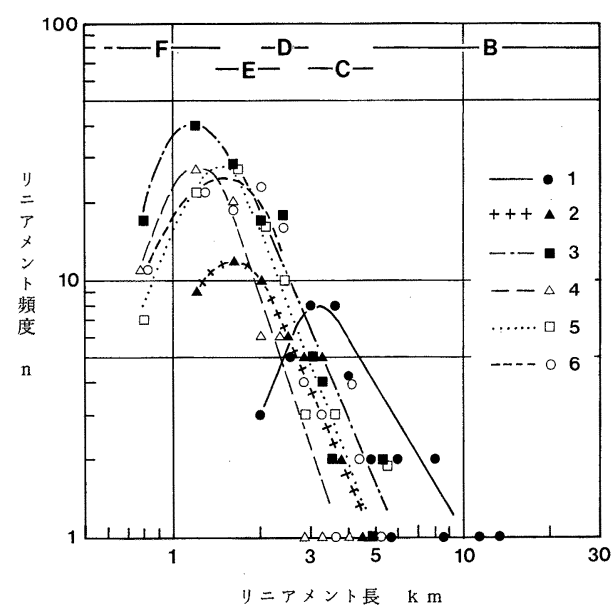

図-2 各地域のリニアメント長別頻度分布

1: アリゾナ州モレンシー地域 2 : ユタ州ビーバー地域 $3:$ 北海道中南部地域 5 : 新潟県東南部地域 $4:$ 青森県北西部地域 $\mathbf{B} \sim \mathbf{F}$ : 評価基準での各ランクの対応範囲

(4)青森県北西部地域

(5)群馬県北西部地域

(6)岐阜県東南部地域

それぞれの地域のリニアメント頻度分布を図 -2 に示 し，以下に各地域の地質構成とリニアメント頻度分布の 特徵を述べる。図-3に 1 例として米国ユタ州ビーバー 地域のリニアメント判読図（一部）を示す。

(1)米国アリゾナ州モレンシー地域

調査地域の地質は, 中央部に先カンブリア紀の花崗岩 および花崗閃緑岩とそれを貫く白亜紀のモンゾナイト斑 岩および花崗斑岩が分布し, 周辺部に先カンブリア系を 不整合に覆ってカンブリア紀から白亜紀の珪質砂岩，石 灰岩および頁岩が分布する17)。

ランドサット TM 画像（縮尺10万分の 1）で判読さ れたリニアメントは総数 38 本で, B ランク 2 本, C ラ ンク13本，D ランク 23 本である。リニアメント長別頻 度では約 3〜 $3.5 \mathrm{~km}$ に最頻值がある。

(2)米国ユタ州ビーバー地域

調査地域は, ベーズンアンドレンジとコロラド平原の 境界部に位置し, ワサッチ構造線の南方延長部に当る。 地質は，主として新第三紀中新世の火山岩類ならびに鮮 新世から更新世の扇状地性堆積物からなる。新第三紀火 山岩類は火山性陥没構造に関連した流紋岩から石英安山 岩質の溶岩類㧍よび同火碎岩, 凝灰岩類で構成され る18)。

空中写真（縮尺約 2 万分の 1 ）で判読されたリニアメ 


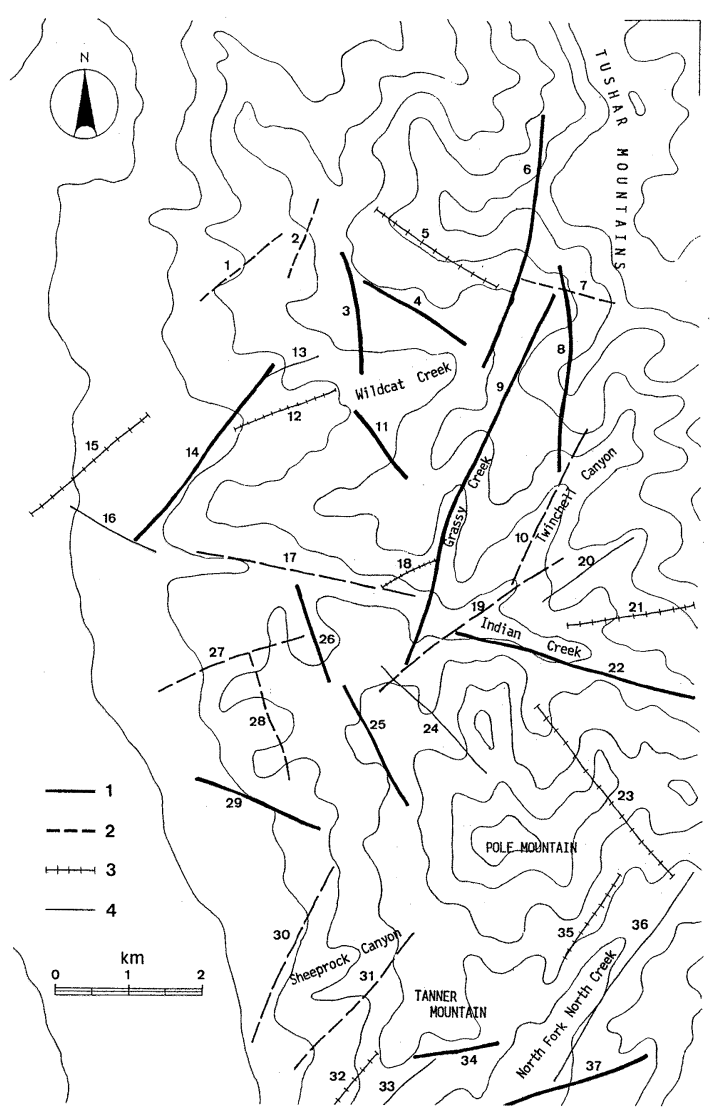

図-3 ユタ州ビーバー地域のリニアメント図（北半部）

1 : 断層に一致するリニアメント

2 : 節理および小断層に一致するリニアメント

$3:$ 岩相境界に一致するリニアメント

$4:$ 成因不明のリニアメント

リニアメント上の数字は整理番号

ントは総数 54 本で, $\mathrm{C}$ ランク 8 本, D ランク 9 本, $\mathrm{E}$ ランク 20 本，F ランク 17 本である。リニアメント長別 頻度では約 $1.7 \mathrm{~km}$ に最頻値がある。

(3)北海道中南部地域

本地域の地質は, 先白鱼系抢よび白带系の輝緑岩, 輝 緑岩質凝灰岩, 砂岩, 頁岩, チャートを主体としてい る。地質構造は西フェルゲンツの構造で, 全体に北北西 一南南東方向の走向を示し, 同方向の褶曲構造と断層な らびに胴切り的な東北東一西南西方向の断層が発達す る19)。

スポット画像でも, 上述の 2 方向のリニアメントが 主に判読され，特に中央部を縱断する北北西一南南東方 向の系統的なリニアメントが特徵的で, 連続性が良く, B ランクに評価される。しかしながら，長いリニアメン
トは別系統のリニアメントで分断されているために，連 続性に欠けることがある。判読されたリニアメントは総 数 134 本で, $\mathrm{B}$ ランク 2 本, $\mathrm{C}$ ランク 9 本, $\mathrm{D}$ ランク 12 本, Eランク 21 本, Fランク 90 本である。リニアメン 卜長別頻度では約 $1 \mathrm{~km}$ に最頻值がある。

(4)青森県北西部地域

本地域は新第三紀グリーンタフ地域に属し，安山岩質 および流紋岩質溶岩・同火砕岩類ならびに泥岩・硬質頁 岩から構成される。地質構造は南北から北西一南東方向 の走向を示し, 東に傾斜する単斜構造からなる20)。

スポット画像では地域西部で南北方向, 地域東部で北 東一南西方向のリニアメントが卓越する。比較的連続性 の良いリニアメントは, 地域中央部の北西方向のリニア メントと地域西部の南北方向のリニアメントであり， C ランクに評価される。判読されたリニアメントは総数 74 本で, Cランク 2 本, $\mathrm{D}$ ランク 2 本, $\mathrm{E}$ ランク 9 本, Fランク 61本である。リニアメント長別頻度では約 1.2 $\mathrm{km}$ に最頻值がある。他の地域と比べて連続性のあるリ ニアメントが少なく， B ランク以上のランクの高いリニ アメントもない。

(5)群馬県北西部地域

本地域は，主に新第三紀の安山岩質および流紋岩質火 砕岩類ならびにそれらを貫く石英閃緑岩・石英斑岩から 構成される21)。これらは東北東一西南西方向および北 西一南東方向の断層で分断され，ブロック化し複雑な地 質構造を呈する。

スポット画像では, 東北東一西南西方向と東西から西 北西一東南東方向のリニアメントが卓越し, 前者の方が 比較的連続性も良い。地域中央部に発達する同方向のリ ニアメントは Cランクに評価される。判読されたリニ アメントは総数 95 本で, Cランク 8 本, D ランク 5 本, $\mathrm{E}$ ランク 8 本， $\mathrm{F}$ ランク 74 本である。リニアメント長 別頻度では約 $1.4 \mathrm{~km}$ に最頻值がある。

6)岐阜県東南部地域

本地域は中生代の花崗岩類および流紋岩類（溶結凝灰 岩類）から構成される ${ }^{22)}$ 。本地域では比較的大規模な 系統的な断層が発達し, 地域東部に南北方向, 地域南西 部に北東一南西方向, 地域北西部に北北東一南南西抢上 び北西一南東方向の断層群が交差する地域に当る。

スポット画像に执いても同様な方向のリニアメントが 明瞭に判読され，これら主要なリニアメントは $\mathrm{A} \sim \mathrm{B}$ ランクに評価される。判読されたリニアメントは総数 111本で, A ランク 1本, B ランク 4 本, Cランク 6 本, $\mathrm{D}$ ランク 8 本， $\mathrm{E}$ ランク 15 本，F ランク 77 本である。 リニアメント長別頻度では約 $1.8 \mathrm{~km}$ に最頻値があるが, 
表-2 リニアメント成因調查結果 ［］：各地域の各ランクでの\%

\begin{tabular}{|c|c|c|c|c|c|c|c|}
\hline & \multirow[t]{2}{*}{ 総本数 } & \multicolumn{6}{|c|}{ リニアメントランク } \\
\hline & & A ランク & B ランク & Cランク & D シンク & Eランク & $\mathrm{F}$ ランク \\
\hline \multicolumn{8}{|l|}{ 断層節理に一致するリリースメト } \\
\hline (1)アリヅナ州モVッシー地域 & $26[68]$ & - & $2[100]$ & $13[100]$ & $11[48]$ & - & - \\
\hline （2）工多州ビーバ -地域 & $36[67]$ & - & - & $8[100]$ & $5[56]$ & $12[60]$ & $11[64]$ \\
\hline (3) 北海道中南部地域 & $35[26]$ & - & $2[100]$ & $8[89]$ & $4[33]$ & $10[48]$ & $11[12]$ \\
\hline (4)青森県北西部地域 & $19[26]$ & - & - & $2[100]$ & $2[100]$ & $4[45]$ & $11[18]$ \\
\hline (5)新潟県南東部地域 & $23[24]$ & - & - & $3[38]$ & $3[60]$ & - & $17\left[\begin{array}{ll}23\end{array}\right]$ \\
\hline (6) 岐阜県南東部地域 & $53[48]$ & $1[100]$ & $4[100]$ & $6[100]$ & $7[88]$ & $9[60]$ & $26[34]$ \\
\hline \multicolumn{8}{|l|}{ 岩相境界に一致するリこアメット } \\
\hline （1）アリリ゙ナ州モレッン-地域 & - & - & - & - & - & - & - \\
\hline (2) I夕州比-バ -地域 & $10[19]$ & - & - & - & $2[22]$ & $4[20]$ & $4[24]$ \\
\hline (3) 北海道中南部地域 & $15[11]$ & - & - & - & - & $1\left[\begin{array}{ll}4 \\
\end{array}\right.$ & $14[16]$ \\
\hline (4) 青森県北西部地域 & $19[26]$ & - & - & - & - & $2[22]$ & $17\left[\begin{array}{l}28 \\
\end{array}\right.$ \\
\hline (5)新潟県南東部地域 & - & - & - & - & - & - & - \\
\hline (6) 岐阜県南東部地域 & $10[9]$ & - & - & - & - & $1\left[\begin{array}{ll}7 & 7\end{array}\right]$ & $9[11]$ \\
\hline \multicolumn{8}{|l|}{ 成因不明のリシアメント } \\
\hline (1)アリゾナ州モレッン-地域 & $12[32]$ & - & - & - & $12[52]$ & - & - \\
\hline (2)工多州ビーーバ-地域 & $8[14]$ & - & - & - & $2[22]$ & $4[20]$ & $2[12]$ \\
\hline (3) 北海道中南部地域 & $84[63]$ & - & - & $1[11]$ & $8[67]$ & $10[48]$ & $65[72]$ \\
\hline (4)青森県北西部地域 & $36[49]$ & - & - & - & - & $3[33]$ & $33[54]$ \\
\hline (5) 新潟県南東部地域 & $72[76]$ & - & - & $5[62]$ & $2[40]$ & $8[100]$ & $57[77]$ \\
\hline (6) 岐阜県南東部地域 & $48[43]$ & - & - & - & $1[12]$ & $5[33]$ & $42[55]$ \\
\hline
\end{tabular}

他の地域に比べて連続性の良いリニアメントが多い。

図-2に示すように各地域の頻度分布は対数正規分布 に近似でき，両対数でほぼ直線上に並ぶ区間が見られ る。この直線から外れるリニアメント長が短い区間は, リニアメントの判読限界を示していると考えられる。判 読限界には，画像の持つ分解能と判読に用いた縮尺から 決定されるものと,リニアメントが地形上の不連続点の 配列であることから 1 つ地形上の不連続があっても リニアメントとしては認識できない点から決定されるも のがある。直線から外れる区間はそれらが複合したもの と考えられるが，現段階ではその区別はなされていな w。

これに対して, 直線になる区間では各直線はランドサ ットTM 画像で判読したモレンシー地域を除きほぼ一 定のばらつき内で一致していると考えられる。モレンシ 一地域とその他の地域との違いは, 他地域では縮尺 5 万分の 1 もしくは 2 万分の 1 , モレンシー地域では 10 万 分の 1 の画像を用いたことによる画像の種類の違いを 反映したものと考えられる。

\section{3 リニアメントの成因に関する現地検証結果}

リニアメントの検証結果を表 -2 に一覧表としてまと め, 図-4 に成因別の頻度分布として示した。

(1)米国アリゾナ州モレンシー地域（図-4 (a)）

本地域では $4 \mathrm{~km}$ 以上の長さのリニアメントの $100 \%$
が断層に一致し，そのすべてが Cランク以上に属する。 また，Dランクでは約50\%が断層に一致した。

(2)米国ユタ州ビーバー地域（図-4 (b))

本地域では $2.4 \mathrm{~km}$ 以上の長さのリニアメントの $56 \%$ が断層に，38\%が節理にそれぞれ一致し，その大半が Cランク以上に属する。 $2.4 \mathrm{~km}$ 未満では, $56 \%$ が断層 もしくは節理に，25\%が岩相境界にそれぞれ一致する。 リニアメントの検証結果の一部を図 -3 に示す。

(3)北海道中南部地域 (図-4 (c))

本地域では $3.0 \mathrm{~km}$ 以上の長さのリニアメントの $91 \%$ が断層に一致し，その大半が Cランク以上に属する。 また, $2.0 \mathrm{~km}$ 以下では岩相境界に一致する割合が高い。 本地域は層理面を持つ急傾斜な層状岩盤, 凝灰岩や頁岩 などのやや軟質な岩石と輝緑岩などの硬質な岩石が分布 することから，比較的短いリニアメントは差別浸食によ る岩相の違いを反映していると考えられる。

(4)青森県北西部地域 (図-4 (d))

本地域では $2.4 \mathrm{~km}$ 以上のリニアメントの $86 \%$ が断層 に一致し，D ランク以上ではすべて断層に一致した。 また, $2.4 \mathrm{~km}$ 末満ではその $27 \%$ が岩相境界に一致し, 他地域に比べて高い率である。本地域は他の地域に比べ て, 地層が新第三紀と新しく，火山岩溶岩を主体として いることや地層の傾斜が緩いことから, 他の地域に比較 して $2.4 \mathrm{~km}$ 以上の長さのリニアメントが極めてそしく, 


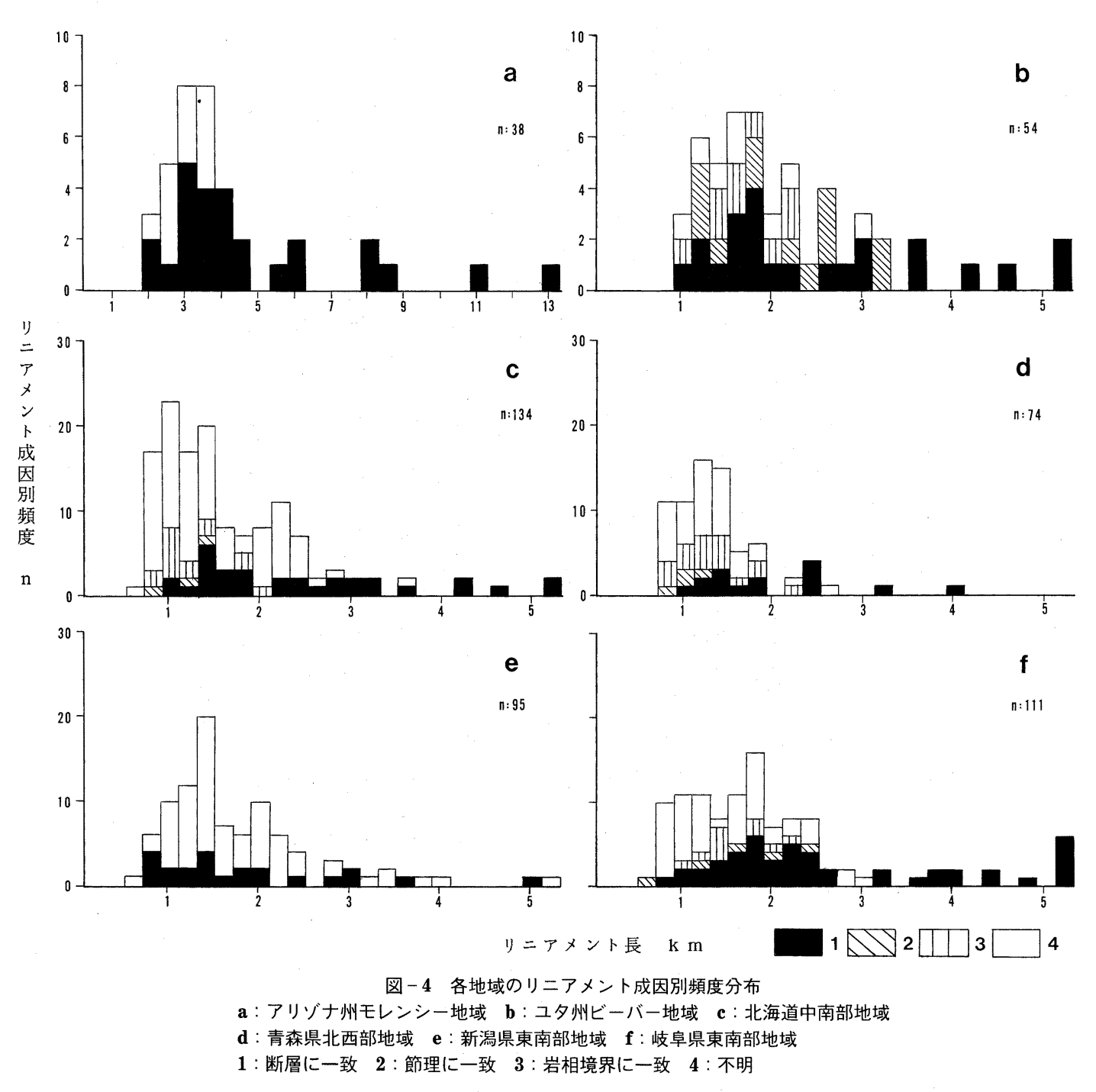

直線性に富んだリニアメントが少なく，岩相境界を示す リニアメントが多い特徵を有する。

(5)群馬県北西部地域（図 $-4(\mathrm{e})$ )

本調査ではトンネルデータのみを利用しているため, 節理や岩相境界とリニアメントの対応の比較はできなか った。リニアメントデータはトンネル周辺に分布してい るものを集計していることで，ランクに対して断層に一 致する割合がやや不規則である。トンネルを横断するリ ニアメントのみに着目すると，20本のうち16本が断層 と一致する。

(6)岐阜県東南部地域（図-4(f)）

本地域では $2.6 \mathrm{~km}$ 以上の長さのリニアメントの $86 \%$ が断層に一致し, その大半は D ランク以上のランクに
属する。他の地域に比較して頻度分布の形が異なり,さ まざまな長さのリニアメントが分布している特徵があ る。なた，Fランクのリニアメントに㧍いても約 $30 \%$ が断層に一致して抢り，他の地域の F ランクよりも割 合が高い傾向がある。

\section{4 リニアメントの成因}

現地調査の結果から, リニアメントはその多くが断層 もしくは節理に一致していると言える。この確率はリニ アメントの連続性（長さ）に規制されており，図-5に 示すような曲線が描ける。曲線からリニアメントが断層 もしくは節理に一致する確率が50\%を越えるリニアメ ント長は空中写真で $1.7 \mathrm{~km}$, スポット画像で $2.3 \mathrm{~km}$, ランドサット TM 画像で $3.0 \mathrm{~km}$ 程度である。また, 確 


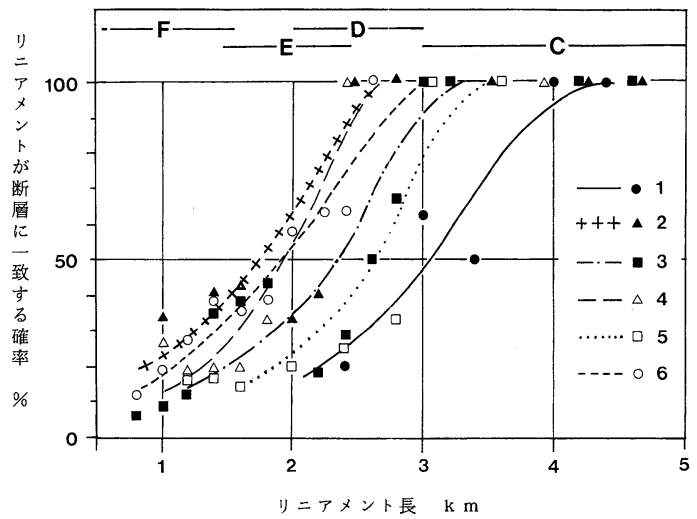

図-5 断層および節理に一致するリニアメントのリニア メント長と断層および節理に一致する確率

1 : アリゾナ州モレンシー地域（ランドサット TM 画像)

2: ユタ州ビーバー地域（空中写真）

$3:$ 北海道中南部地域（スポット画像）

4: 青森県北西部地域（スポット画像）

$5:$ 新潟県東南部地域（スポット画像）

6 : 岐阜県東南部地域（スポット画像）

$\mathbf{C} \sim \mathbf{F}$ : 評価基準での各ランクの対応範囲

率が100\%になるリニアメント長は空中写真で $2.5 \mathrm{~km}$, スポット画像で $3.0 \mathrm{~km}$, ランドサット TM 画像で 4.0 $\mathrm{km}$ 程度である。大野・小島副は割れ目の長さ分布でフ ラクタル分布に当るのが超過確率で50\%より小さい部 分(平均値よりも大きい割れ目)であることを示したが, 本研究の地域ではこの值は空中写真およびスポット画像 でほぼ2.2 3 km, ランドサット TM 画像で $4 \mathrm{~km}$ であ り，断層もしくは節理に一致する確率が $100 \%$ を越える 值とほほ整合的である。このことは, 図-2 の頻度分布 に抢いて直線区間の規模のリニアメントは断層もしくは
節理にほぼ一致すると推定できる。しかしながら，直線 区間でのばらつきの評価が必要であり，今後の問題とし てばらつきの評価が残されている。

また, 調查結果を地層別に区分してまとめると表 -3 のようになる。結晶質岩地域（先カンブリア紀～第三紀） は火山岩地域（新第三紀）に比べて, 長いリニアメント から短いリニアメントをで広く分布し, 長いリニアメン 卜ほど断層に一致する確率が高い。また, 火山岩地域は 結晶岩地域に比べて, 岩相境界に一致するリニアメント が多い。このことは, 古い時代の地層（特に結晶質岩） が分布する地域は, 断層の活動が繰り返して生じている ために破砕規模が大きく, 断層が地形的に反映されやす いと考えられる。また, 火山岩地域では溶岩の流理面, 堆積岩地域（白亜紀）では地層の層理面に影響をうけ差 別浸食が進み, 岩相境界に一致するリニアメントが比較 的多いと考えられる。

\section{5. リニアメントの長さと断層破砕幅の関係}

断層と一致したリニアメントについて, 現地調査やト ンネルデータで得られた断層破碎幅とリニアメント長と の関係を図-6に示す。リニアメントランク区分と断層 破碎幅は, 破砕幅とランク区分が両対数上で直線の良い 相関を示している。おおむね, B ランクでは破砕幅 $20 \sim 60 \mathrm{~m}$ : 平均 $36 \mathrm{~m}, \mathrm{C}$ ランクでは破砕幅 $3 \sim 25 \mathrm{~m}$ : 平 均 $11 \mathrm{~m}, \mathrm{D}$ ランクでは破砕幅 $1 \sim 10 \mathrm{~m}$ : 平均 $4 \mathrm{~m}, \mathrm{E}$ お よび $\mathrm{F}$ ランクでは破砕幅 $0.2 \sim 2 \mathrm{~m}:$ 平均 $0.7 \mathrm{~m}$ という結 果になった。このことは,リニアメント評価表に基づく ランク区分から断層の破砕幅をある程度推定することが できることを示している。また, 地層別では, 先第三系 の分布する地域での断層が数 $10 \mathrm{~cm}$ 数 $10 \mathrm{~m}$ のレンジ の広い破碎幅を示すのに対して，第三系の分布する地域

表 - 3 岩相の違いによるリニアメント成因の傾向［］：各地域の各ランクでの\%

\begin{tabular}{|c|c|c|c|c|c|c|c|c|c|}
\hline \multirow{2}{*}{$\begin{array}{l}5 \\
y \\
y\end{array}$} & \multicolumn{3}{|c|}{ 結晶質岩類 } & \multicolumn{3}{|c|}{ 堆積岩類 } & \multicolumn{3}{|c|}{ 火山岩類 } \\
\hline & 断層節理 & $\begin{array}{l}\text { 岩想 } \\
\text { 境界 }\end{array}$ & 不明 & 断層 節理 & $\begin{array}{l}\text { 碳相 } \\
\text { 境界 }\end{array}$ & 不明 & 断層 節理 & $\begin{array}{l}\text { 崖相 } \\
\text { 㜔界 }\end{array}$ & 不明 \\
\hline A & $1[100]$ & - & - & - & - & - & - & - & - \\
\hline B & $6[100]$ & - & - & $2[100]$ & - & - & - & - & - \\
\hline C & $22[81]$ & - & $5\left[\begin{array}{ll}19 \\
0\end{array}\right.$ & $8\left[\begin{array}{ll}89 \\
0\end{array}\right.$ & - & 1 [11] & $10[100]$ & - & - \\
\hline D & $21[58]$ & - & $15[42]$ & $4\left[\begin{array}{l}33] \\
0\end{array}\right.$ & - & $8[67]$ & $7[64]$ & $2[18]$ & $2[18]$ \\
\hline $\mathrm{E}$ & $9[39]$ & $1[4]$ & $13[57]$ & $10[48]$ & $1[4]$ & 10 [48] & $16[55]$ & $6[21]$ & $7[24]$ \\
\hline $\mathrm{F}$ & $43[28]$ & $9[6]$ & $99[66]$ & $11[12]$ & $14[16]$ & 65 [72] & $22[28]$ & $21[27]$ & 35 [45] \\
\hline & $102[42]$ & $10[4]$ & $132[54]$ & $35\left[\begin{array}{ll}26\end{array}\right]$ & $15[11]$ & 84 [63] & $55[43]$ & $29[23]$ & 44 [34] \\
\hline
\end{tabular}

結晶質岩地域 : アリゾナ州モレンシー十群馬県＋岐阜県

堆積岩地域: 北海道 火山岩地域: ユタ州ビーバー+青森県 
では, 数 $\mathrm{m}$ 程度の破砤幅を示す断層が多い傾向が見ら れる。

断層破碎幅と断層長については, 緒方ほか ${ }^{233}$ は花崗 岩地域に㧍いてトンネル通過地抢よびダムの掘削面など で確認した断層の長さ $(L)$ とその破砕幅 $(T)$ の関係 を次式で示した。

$$
\log L=0.68 \pm 0.32+0.87 \log T
$$

この関係式をリニアメントから得られた破砕幅と比較 すると，リニアメント長が $3 \mathrm{~km}$ 以上では比較的良く一 致しているが, $3 \mathrm{~km}$ 以下では破碎幅がやや小さくなる 傾向がある。この原因としては，緒方ほか23)で用いら れたデータが断層長約 $4 \mathrm{~km}$ 以上，断層破砕幅約 $20 \mathrm{~m}$ 以上のものと断層長約 $0.2 \mathrm{~km}$ 以下, 断層破砕幅約 $1 \mathrm{~m}$ 以下のものから相関を議論していること，また， $3 \mathrm{~km}$ 以下では破砕幅が小さいと考えるよりも， $3 \mathrm{~km}$ 以下の 長さで同じ破砕幅では, リニアメント長が実際の断層長 よりも長くなる傾向があることなどが考えられる。事 実, 判読では, $3 \mathrm{~km}$ 以下のリニアメントを構成してい る地形は低次の谷を含んでいる場合が多く，連続して判 読する際に浸食作用のみの谷を含む可能性がある。な お，上述の破砝幅は平均的な破确幅を表していると考え られるが，断層タイプによって破砕様式の違いがあり， 詳細な地質構造学的検討が必要である。

検証調査によって，評価基準でランク区分されたリニ アメントのうち，Eランク以下のリニアメントについて は断層と一致する確率が D ランクよりも格段に低く， 断層に一致するものについても破砕幅が最大でも $2 \mathrm{~m}$ 以下であった。また，リニアメントのランクと破砕幅と の関係についても，ランクが高くなる程破碎幅が大きく なることが明らかにされた。このことから，目的に応じ た断層調查によって，各ランクのリニアメントに着目す ることで，有効な地質構造調査が可能である。C・D ンク以上のリニアメントを対象とした場合には衛星画像 （ランドサット TM 画像もしくはスポット画像）を， E ・F ランクを対象とした場合には空中写真を適切な縮尺 で判読することでその評価が可能である。

\section{6. ま め}

リニアメントの評価基準を作成し，現地調查および既 存断層データから検証調査を行うことにより，次の結果 を得た。

（1）現地調査の結果から，リニアメントはその多 くが断層もしくは節理に一致しており，その確率はリニ アメントの連続性（長さ）に規制されている。リニアメ ントが断層もしくは節理に一致する確率が $100 \%$ になる

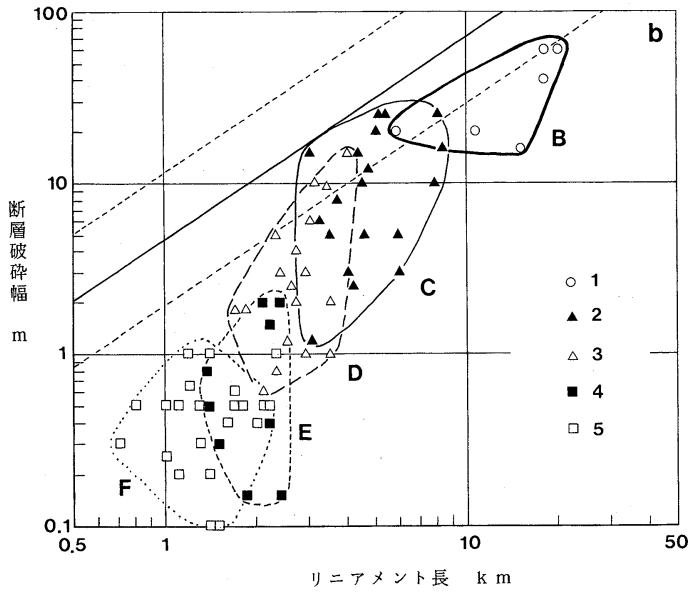

図-6 リニアメント長と断層破砕幅の関係

$1: B$ ランク $\quad 2: \mathrm{C}$ ランク $3: \mathrm{D}$ ランク

$4: \mathrm{E}$ ランク $5: \mathrm{F}$ ランク

図中の直線は, 緒方・本荘の関係式 23

リニアメント長は空中写真で $2.5 \mathrm{~km}$ ，スポット画像で $3.0 \mathrm{~km}$ ，ランドサット TM 画像で $4.0 \mathrm{~km}$ 程度である。

（2）大野ほか10)が示したフラクタル分布になる超 過確率で $50 \%$ より小い部分は, 本論の地域での断層 もしくは節理に一致する確率が $100 \%$ を越える值とほぼ 整合的である。頻度分布において直線区間の規模のリニ アメントは断層もしくは節理にほほ一一致すると推定でき る。

（3）結晶質岩地域（先カンブリア紀〜第三紀）は 火山岩地域（新第三紀）に比べて，長いリニアメントか ら短いリニアメントまで広く分布し，長いリニアメント ほど断層に一致する確率が高い。また，火山岩地域は結 晶岩地域に比べて, 岩相境界に一致するリニアメントが 多い。

（4）リニアメントランク区分と断層破砝幅の関係 は, 破砕幅とランク区分が両対数上で良い相関を示して いる。このことは,リニアメント評価表に基づくランク 区分から断層の破砕幅をある程度推定することができる ことを示唆している。

（5）各断層調査のレベルに応じて，各ランクのリ ニアメントに着目することによって, 有効な地質構造調 查が可能である。C・D ランク以上のリニアメントには 衛星画像（ランドサット TM 画像もしくはスポット画 像）を, E・F ランクでは空中写真を適切な縮尺で判読 することでその評価が可能である。 
謝辞 本研究に当って，現地調査に同行していただき， 討論していただいた(財)電力中央研究所 本荘靜光主任研 究員・千木良雅弘博士に感謝します。また，データ収集 ならびに現地調査に同行していただいた住鉱コンサルタ ント(侏) 根本 徹・長瀬真央・中島英俊の各氏に感謝し ます。

\section{参 考 文 献}

1）水落幸広・角南基亮・丸山裕一（1988）：資源探査におけ る衛星画像判読・解析手法の再検討, 日本測量調査技術協 会誌 APA, No. $39-12$, pp. $79-83$

2）土木学会・原子力土木委員会（1985）：原子力発電所地質 ・地盤の調査・試験法および地盤の耐震安定性の評価手 法報告書 第二編 地質調査法, pp. 4-17

3）岸 清·桑原 洋・澤田臣啓 (1985): 福島県浜通り地方 の地質, 電力土木, No. 194 , pp. $24-32$

4）越谷 信 - 長江亮二 ·大上和良・森田安彦 (1991) : 南部 阿武郎山地花崗岩体中の断裂系と地下水, 応用地質, vol. 32 , No. 4 , pp. $23-39$

5）山口靖・長谷紘和（1983）：多様な画像によるリニアメン 卜頻度の解析一レーダ画像の屋久島地域への適用例につ いて—，写真測量とリモートセンシング, Vol. 22, pp. 4 $-13$.

6) HOBBS, W. H. (1904): Lineaments of Atlantic Border Region., Bull. Geol. Soc. Amer., Vol. 15, pp. $483-506$

7) American Geological Institute (1980): Glossaly of Geology “lineament", p. 380

8）小島圭二・大野博之・亀谷裕志（1987）：フラクタル的な 岩盤評価の可能性, 昭和62年度日本応用地質学会研究発 表会講演論文集, pp. 53-56

9）佐藤邦明・市川正憲（1987）：岩盤フラクチャーのフラク タル次元と水理特性の相関, 土と基礎, Vol. 35, pp. $13-$ 18

10）大野博之・小島圭二 (1988): 岩盤中の割れ目系にみられ るフラクタル, 応用地質, Vol. 29, No. 4, pp. 11-18
11）星野一男・松野久也（1974）：アーツ映像より見た南関東 の断裂系一とくに南北性断裂について一，地質ニュース， No. 235 , pp. $1-13$

12）星野一男・長谷紘和（1977）：神縄断層を切る南北性断層 について, 地質学雑誌, Vol. 83, pp. 62-64

13）村岡洋文・長谷紘和（1980）：陥没カルデラに由来する環 状地形構造の評価, 地質ニュース, No. 311, pp. 7-29

14）山口靖・長谷紘和・村岡洋文 (1984)：リモートセンシン グからのリニアメント解析の問題点, 日本地質学会 第 91 年学術大会講演要旨, pp. 503

15）山口靖（1984）：リニアメント解析における低腑角 SAR 画像の照射方向の効果, 日本リモートセンシング学会誌, Vol. 4, pp. $5-15$

16）吾妻高志 (1986)：SLAR 映像とその地質判読における有 効性, 石油資源開発(侏研究報告, No. 3, pp. 36-82

17) LINDGREN, W. and BOUTWELL, J. M. (1905): Description of The Clipton Quadrangle, Arizona, U. S. Geological Survey, scale $1: 62,500$

18) MACHETTE, M. N., STEVEN, T. A., CUNNINGHAM, C. G. and ANDERSON, J. J. (1984): Geologic Map of The Beaver Quadrangle, Beaver and Piute Counties, UTAH, U. S. Geological Survey Miscellaneous Investigations Series Map I-1520, scale 1:50,000

19）井上大榮・田中和広（1986）：日高帯中を通過するトンネ ルの事前地質調查と掘削結果, 北村信教授記念地質論文集, pp. $113-121$

20）日本鉄道建設公団青函建設局（1989）：青函トンネル地質 図, 53p.

21） 日本道路公団東京第二建設局（1986）：関越トンネル工事 誌 (資料編)，52p.

22）日本道路公団名古屋建設局（1978）：恵那山トンネル工事 誌 (資料編)，37p.

23）緒方正虎・本荘靜光（1981）：電力施設の耐震設計に扔け る断層活動性の評価, 応用地質, Vol. 22, No. 1, pp. $67-$ 86

（1992年 2 月 24 日受付，1992年 4 月 21 日受理） 